\title{
Pengaruh Likuiditas Dan Perputaran Modal Kerja Terhadap Profitabilitas \\ Pada PT Smart Tbk. Periode Tahun 2011-2019
}

\author{
Nur Annisa Oktaviani Sofyan dan Richad Alamsyah \\ Program Studi S1 AkuntansiFakultas Bisnis \\ Institut Bisnis Dan Informatika KesatuanBogor
}

E-Mail : na.oktaviani@gmail.com
Financial

Performance in

Manufacturer

\section{ABSTRACT}

The development of the era of globalization has made the business world in Indonesia continue to grow so that it has increased significantly from year to year. Thisis an attraction that spurs investors to invest their capital, especially with the implementation of free trade which encourages investors to take business units in various parts of the world or become new competitors in similar industries. Competitionthat occurs requires companies to be more competitive so as not to lose to compete withother companies. Therefore, to maintain the survival of the company and generate optimal profits, the company must be able to manage its finances well, meaning that financial management policies must be able to ensure the company's business continuity, by increasing all company activities and optimizing the resources they haveproperly. must be smart and fast in taking appropriate steps to anticipate the development of the business world with productivity competitiveness based on production efficiency and effectiveness. This study aims to obtain findings about (1) the effect of liquidity and working capital turnover partially on profitability, (2) the effect of liquidity and working capital turnover simultaneously on profitability. The type of data used in this study is secondary data, namely the quarterly financial statements of PT SMART Tbk for the period 2011-2019. The analysis used in this study is multiple linear regression analysis using the Statistical Package for Social Sciences (SPSS) version 25 program. The total sample used by the author is 36 data. The results showed that liquidity had an effect on profitability. Working capital turnover has no effect on profitability. Liquidity and working capital turnover together have a positive effect on company profitability.

Keywords: Liquidity, Working Capital Turnover, Profitability

\begin{abstract}
ABSTRAK
Perkembangan era globalisasi yang membuat dunia bisnis di Indonesia terus berkembang sehingga mengalami peningkatan yang cukup signifikan dari tahun ke tahun. Hal ini menjadi daya tarik yang memacu para investor untuk menanamkan modalnya, terlebih lagi dengan diberlakukannya perdagangan bebas yang mendorong para investor untuk unit bisnis di berbagai belahan dunia atau menjadi pesaing baru dalam industri sejenis. Persaingan yang terjadi menuntut perusahaan untuk dapat lebihberkompetitif agar tidak kalah bersaing dengan perusahaan lainnya. Oleh karena itu, untuk menjaga kelangsungan hidup perusahaan dan menghasilkan laba yang optimal, maka perusahaan harus mampu mengelola keuangannya dengan baik, artinya kebijakan pengelolaan keuangan harus dapat menjamin kebelangsungan usaha perusahaan, dengan cara meningkatkan seluruh aktivitas perusahaan dan mengoptimalkan sumber daya yang dimiliki dengan baik, harus cerdas dan cepat dalam mengambil langkah- langkah yang tepat untuk mengantisipasi perkembangan dunia bisnis dengan daya saingproduktivitas yang dilandasi efisiensi dan efektifitas produksi. Penelitian ini bertujuan untuk memperoleh temuan tentang (1) pengaruh likuiditas dan perputaran modal kerja secara parsial terhadap profitabilitas, (2) pengaruh likuiditas dan perputaran modal kerja secara simultan terhadap profitabilitas. Jenis data yang digunakan dalam penelitian ini adalah


Financial

Performance in

Manufacturer data sekunder, yaitu laporan keuangan triwulan PT SMART Tbk periode tahun 20112019. Analisis yang digunakan dalam penelitian ini adalah analisis regresi linear berganda dengan menggunakan program Statistical Package for Social Sciences (SPSS) versi 25. Total sampel yang digunakan penulis sebanyak 36 data. Hasil penelitian menunjukan bahwa likudiitas berpengaruh terhadap profitabilitas. Perputaran modal kerja tidak berpengaruh terhadap profitabilitas. Likuiditas dan perputaran modal kerja secara bersama-sama berpengaruh positif terhadap profitabilitas perusahaan.

Kata Kunci: Likuiditas, Perputaran Modal Kerja, Profitabilitas

\section{$\underline{374}$}

\section{PENDAHULUAN}

Seiring dengan perkembangan era globalisasi yang membuat dunia bisnis di Indonesia terus berkembang sehingga mengalami peningkatan yang cukup signifikan dari tahun ke tahun. Hal ini didukung oleh sumber daya alamdan sumber daya manusia yang ada di negara ini, sehingga menjadi daya tarikyang memacu para investor untuk menanamkan modalnya, terlebih lagi dengan diberlakukannya perdagangan bebas yang mendorong para investor untuk unit bisnis di berbagai belahan dunia atau menjadi pesaing baru dalam industri sejenis. Persaingan yang terjadi menuntut perusahaan untuk dapat lebih berkompetitif agar tidak kalah bersaing dengan perusahaan lainnya. Olehkarena itu, untuk menjaga kelangsungan hidup perusahaan dan menghasilkanlaba yang optimal, maka perusahaan harus mampu mengelola keuangannya dengan baik, artinya kebijakan pengelolaan keuangan harus dapat menjamin keberlangsungan usaha perusahaan, dengan cara meningkatkan seluruh aktivitas perusahaan dan mengoptimalkan sumber daya yang dimiliki dengan baik, harus cerdas dan cepat dalam mengambil langkahlangkah yang tepat untuk mengantisipasi perkembangan dunia bisnis dengan daya saing produktivitas yang dilandasi efisiensi dan efektifitas produksi.

Sayangnya pada akhir tahun $2019 \mathrm{iklim}$ usaha di dunia khususnya di Indonesia tidak begitu baik, yakni terjadinya wabah COVID-19 yang membuatperekonomian dunia porak-poranda. Dalam kondisi pandemi Covid-19 inimembawa dampak yang sangat besar yaitu membuat penurunan pendapatan secara global, terutama di Indonesia banyak perusahaan yang mengalami penurunan pendapatan akibat kondisi ini, seperti di sektor pariwisata, perhotelan, pertambangan, jasa, properti dan lain-lain. Namun disamping itu terdapat juga perusahaan kontra indikasi yang masih bertahan dan bahkan berkembang dalam kondisi pandemi ini seperti, sektor pertanian dan industri kelapa sawit salah satunya PT Sinar Mas Agro Resources and Technology Tbk atau disingkat sebagai PT SMART Tbk adalah perusahaan publik produk konsumen berbasis kelapa sawit yang terintegrasi dan terkemuka di Indonesiayang berfokus pada produksi minyak sawit yang lestari dengan pengelolaan perkebunan seluas 139.300 hektar (termasuk perkebunan plasma).

Berdasarkan informasi yang penulis dapatkan dari media online yang menginformasikan:

"Bisnis industri perkebunan tidak terlalu berdampak Covid-19 dibanding sektor perbankan dan properti. Dimana saat ini negara pengimpor hasil bisnis perkebunan masih menerima produk Sinar Mas untuk bahan baku pangan, selain itu kebijakan penggunaan Biodiesel B30 membuat sektor perkebunan sawit masih dapat terus bertahan."

(cnbcindonesia.com)

Didirikannya suatu perusahaan tentunya memiliki tujuan yaitu untuk memenuhi kebutuhan manusia akan produk-produk dan mempertahankan eksistensi perusahaan dengan cara meningkatkan seluruh aktivitas perusahaandan mengoptimalkan sumber daya yang dimiliki agar perusahaan mencapai laba yang maksimal. Laba yang diperoleh dapat dimaksimalkan melalui peningkatan penjualan produk dan meminimalkan biaya operasional. Untuk mengukur efisiensi aktivitas suatu perusahaan dalam memperoleh laba dapat diukur dengan menggunakan rasio profitabilitas.

Menurut Carl S. Warren (2012), keuntungan atau laba adalah selisih antara jumlah 
yang diterima dari pelanggan atas barang dan jasa yangdihasilkan dan biaya yang dikeluarkan untuk input yang digunakan guna menghasilkan barang atau jasa. Dalam mencapai laba yang optimal perusahaan perlu melakukan penjualan. Penjualan bisa berupa barang atau jasa yang menjadi sumber pendapatan perusahaan. Agar penjualan dapat terlaksana dengan baik maka perusahaan harus melakukan kegiatan produksi. Dalam melakukan kegiatan produksi tentunya memerlukan modal kerja untukkegiatan operasionalnya, misalnya untuk membayar upah buruh dan gaji pegawai, pembelian bahan baku, melunasi pinjaman-pinjaman jangka pendeknya, dan biaya-biaya lainnya. Sejumlah dana yang telah dikeluarkan untuk melakukan kegiatan produksi tersebut diharapkan akan dapat kembali lagi masuk dalam perusahaan dalam jangka waktu pendek melalui hasilpenjualan barang dagangan atau hasil produksinya. Dana yang masuk yang bersumber dari hasil penjualan barang tersebut akan dikeluarkan kembali gunamembiayai operasi perusahaan selanjutnya. Dengan demikian, dana tersebut akan berputar secara terus-menerus setiap periodenya sepanjangberoperasinya perusahaan. Sumber dan penggunaan modal kerja sangat penting, di sampingmasalah modal kerja ini erat hubungannya dengan operasi perusahaan sehari-hari juga menunjukkan tingkat keamanan atau margin of safety para kreditur terutama kreditur jangka pendek. Adanya modal kerja yang cukup sangat penting bagi suatu perusahaan karena dengan modal kerja yang cukup itu memungkinkan bagi perusahaan untuk beroperasi dengan seekonomis mungkin dan perusahaan tidak mengalami kesulitan atau menghadapi bahaya-bahaya yang mungkin timbul karena adanya krisis atau kekacauan keuangan.

Akan tetapi adanya modal kerja yang berlebihan menunjukkan adanya dana yang tidak produktif, dan hal ini akan menimbulkan kerugian bagiperusahaan karena adanya kesempatan untuk memperoleh keuntungan telah disia-siakan. Sebaliknya adanya ketidak-cukupan dalam modal kerja merupakan sebab utama kegagalan suatu perusahaan.

Masa perputaran modal kerja dimulai dari saat kas diinvestasikan dalamkomponen modal kerja hingga menjadi kas lagi selama kurang dari satu tahunatau berjangka pendek. Masa perputaran modal kerja ini menunjukkan tingkatefisiensi penggunaan modal kerja tersebut. Semakin cepat masa perputaran modal kerja maka semakin efisien penggunaan modal kerja, dan tentunya investasi pada modal kerja semakin kecil. Begitupun sebaliknya semakinlambat masa perputaran modal kerja maka semakin tidak efisien penggunaanmodal kerja, dan tentunya investasi pada modal kerja semakin besar. Modal kerja dapat diartikan sebagai kelebihan aset lancar terhadap hutang jangka pendek. Kelebihan ini berasal dari hutang jangka panjang dan modal sendiri yang disebut dengan modal kerja bersih (Working Capital Turnover). Kemampuan suatu perusahaan untuk membayar hutang sedemikian besarnya sehingga mampu memenuhi segala kewajiban finansialnya yang harus segera dipenuhi, dapat dikatakan bahwa perusahaan tersebut disebut likuid dan sebaliknya jika perusahaan tersebut tidak memiliki kemampuan untuk membayar disebut tidak likuid.

Bilamana dikaitkan dengan siklus operasi normal perusahaan yaitu mencakup siklus pembelian-penjualan-penagihan. Likuiditas merupakan salah satu faktor yang menentukan sukses atau gagalnya manajemen keuangan perusahaan. Jumlah alat pembayaran yang dimiliki perusahaan menjadi sumber kekuatan perusahaan dalam membayar kewajiban yang harus dibayarkan. Makin tinggi likuiditas maka makin baiklah posisi perusahaan di mata kreditur, namun disisi lain terdapat beban kesempatan (opportunity cost) yangcukup material. Hal ini memberi arti, bila perusahaan memutuskan menetapkan modal kerja dalam jumlah yang besar, kemungkinan tingkat likuiditas akan terjaga namun kesempatan untuk memperoleh laba akan menurun yang padaakhirnya berdampak pada menurunnya profitabilitas, sebaliknya jika perusahaan ingin memaksimalkan profitabilitas, kemungkinan dapat mempengaruhi tingkat likuiditas perusahaan.

Hasil dari penelitian Selin Lumoly, Sri Murni, dan Victoria N. Untu (2018)dengan judul Pengaruh Likuiditas, Ukuran Perusahaan dan Profitabilitas Terhadap Nilai Perusahaan pada Perusahaan Logam dan Sejenisnya yang Terdaftar di Bursa Efek Indonesia Periode

\author{
Financial \\ Performance in \\ Manufacturer
}

375 
Financial

Performance in

Manufacturer

2013-2017. Menyatakan bahwa secara parsial variabel likuiditas (CR) dan ukuran perusahaan (Size) tidak berpengaruh terhadap nilai perusahaan (PBV), sedangkan variabel profitabilitas(ROE) berpengaruh terhadap nilai perusahaan (PBV). Dan secara simultan Likuiditas (CR) ukuran perusahaan (Size) dan profitabilitas (ROE) memiliki pengaruh terhadap nilai perusahaan (PBV).

Begitu pula dengan penelitian Syarah Ajie Wijayanti (2018) dengan judul Analisis Pengaruh Likuiditas, Perputaran Modal Kerja dan Pertumbuhan Penjualan Terhadap Profitabilitas Perusahaan Pada Perusahaan Food and Beverages yang Terdaftar Di BEI Periode 2012-2016. Menyatakan bahwa variabel-variabel independen (Likuiditas, Perputaran Modal Kerja, dan Pertumbuhan Penjualan) secara simultan (uji F) berpengaruh terhadap Profitabilitas sedangkan secara parsial (uji t) menunjukkan bahwa variabel Likuiditas tidak berpengaruh terhadap Profitabilitas, variabel Perputaran Modal Kerja berpengaruh signifikan terhadap Profitabilitas, dan variabel PertumbuhanPenjualan berpengaruh signifikan terhadap Profitabilitas. Hasil penelitian dari Linda Ratnasari (2016) dengan judul Pengaruh Leverage, Likuiditas, Ukuran Perusahaan Terhadap Profitabilitas Pada Perusahaan Otomotif Di BEI Periode 2009-2014. Menyatakan bahwa Leverage berpengaruh signifikan dan negatif terhadap profitabilitas, Likuiditas berpengaruh tidak signifikan terhadap profitabilitas, demikian juga ukuran perusahaan berpengaruh tidak signifikan terhadap profitabilitas.

Tabel 1.Rata-rata Profitabilitas Pada PT SMART Tbk Periode 2011-2019

\begin{tabular}{|c|c|}
\hline Tahun & Profitabilitas (ROA) \\
\hline 2011 & 0,09 \\
\hline 2012 & 0,09 \\
\hline 2013 & 0,05 \\
\hline 2014 & 0,06 \\
\hline 2015 & $-0,01$ \\
\hline 2016 & 0,07 \\
\hline 2018 & 0,02 \\
\hline 2019 & 0,00 \\
\hline
\end{tabular}

Sumber: Data diolah dari laporan keuangan kuartalan PT SMART Tbk periode 20112019

Berdasarkan Tabel 1. dapat dilihat bahwa PT SMART Tbk. dari tahun 2011-2019 yaitu mengalami fluktuasi jumlah profitabilitas. Dan dapat kita lihatpada tahun 2015 dan 2018 profitabilitas PT SMART Tbk sebesar $-0,01$ dan 0,00 .Hal ini disebabkan karena PT SMART Tbk pada tahun tersebut mengalami kerugian.

Tabel 2. Faktor-Faktor Penurunan Profitabilitas

\begin{tabular}{|l|l|l|}
\hline No & Tahun & Faktor Penurunan Profitabilitas \\
\hline 1 & 2015 & $\begin{array}{l}\text { Laba bersih menurun karena tertekannya harga minyak sawit(CPO) } \\
\text { yang diakibatkan dari merosotnya harga minyak mentah dan } \\
\text { melimpahnya panen kedelai, serta terjadinya fenomena cuaca kering } \\
\text { (El Nino) yang parah yang } \\
\text { mengakibatkan penurunan produksi. }\end{array}$ \\
\hline 2 & 2018 & $\begin{array}{l}\text { Laba bersih menurun karena dipengaruhi oleh rugi selisih } \\
\text { kurs yang cukup besar, terutama berasal dari translasipinjaman } \\
\text { berdenominasi Dollar AS ke Rupiah. }\end{array}$ \\
\hline
\end{tabular}

Sumber: www.smart-tbk.com (Data Diolah dari Annual Report)

Perusahaan sektor industri kelapa sawit dipilih karena tidak menutup kemungkinan bahwasannya perusahaan ini dibutuhkan oleh masyarakat sehingga prospeknya menguntungkan baik dimasa sekarang dan dimasa yangakan datang. Dan kondisi perusahaan tersebut yang paling tahan dengan krisismoneter atau ekonomi di masa pandemi Covid-19 ini, dibandingkan dengan sub sektor lain karena dalam kondisi apapun krisis maupun tidak krisis sebagian produk kelapa sawit tetap dibutuhkan karena merupakan kebutuhan primer manusia selain pakaian dan tempat tinggal. 
Tujuan dari penelitianini adalah sebagai berikut:

1. Untuk menguji bagaimana likuiditas berpengaruh terhadap profitabilitas PTSMART Tbk.

2. Untuk menguji bagaimana perputaran modal kerja berpengaruh terhadap profitabilitas PT SMART Tbk.

3. Untuk menguji bagaimana likuiditas dan perputaran modal kerjaberpengaruh secara simultan terhadap profitabilitas PT SMART Tbk.

\section{Kerangka Pemikiran Teoritis/Konseptual}

Model penelitian ini digambarkan dengan kerangka pemikiran teoritis/konseptual sebagai berikut:

\section{Hipotesis Penelitian}

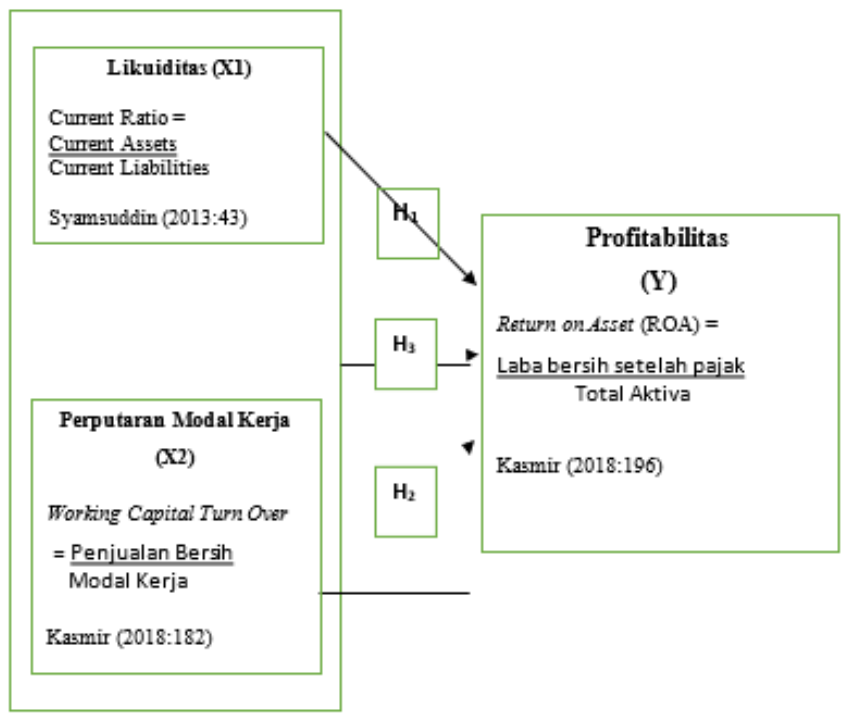

\section{Gambar 1. Kerangka Pemikiran}

Hipotesis berdasarkan paradigma diatas maka dibutuhkan suatu pengujian hipotesis untuk mengetahui apakah terdapat hubungan antara variabel independent terhadap variabel dependent.

Hipotesis merupakan kesimpulan jawaban sementara dari penelitian yang akan dilakukan, dan hanya berdasarkan teori-teori yang didapat, serta perlu diuji kebenarannya lebih lanjut. Penyusunan belum berdasarkan penelitian langsung atau riset pada perusahaan. Dari uraian di atas penulis dapat merumuskan hipotesis atau kesimpulan sementara dengan tiga hipotesispenelitian yang dapat diajukan yaitu:

H1 : Likuiditas berpengaruh positif terhadap profitabilitas.

$\mathrm{H} 2$ : Perputaran modal kerja berpengaruh positif terhadap profitabilitas.

$\mathrm{H} 3$ : Likuiditas dan perputaran modal kerja berpengaruh positif secara simultanterhadap profitabilitas.

\section{METODE PENELITIAN}

Obyek penelitian ini adalah Likuiditas yang diproyeksikan dengan Current Ratio (CR) dan perputaran modal kerja yang diproyeksikan dengan working capital turnover yang mempengaruhi Profitabilitas yang diproyeksikandengan Return on Assets (ROA). Subjek penelitian ini adalah PT SMART Tbk. periode 2011-2019. PT SMART Tbk. ini didirikan tahun 1962 dan tercatat di Bursa Efek Indonesia sejaktahun 1992, PT Sinar Mas Agro Resources and Technology Tbk (SMART) yang merupakan salah satu perusahaan publik produk konsumen berbasis kelapa sawit yang terintegrasi dan terkemuka di Indonesia, menghasilkan penjualan sebesar Rp 36,2 triliun pada tahun 2019.

Populasi dalam penelitian ini berupa laporan keuangan PT SMART Tbk. Teknik pemilihan sampel dalam penelitian ini adalah nonprobability sampling yang merupakan prosedur penarikan sampel yang bersifat subjektif, dalam hal ini probabilitas pemilihan elemen-elemen populasi tidak dapat ditentukan karena setiap elemen dalam populasi 
Financial Performance in Manufacturer tidak memiliki peluang yang sama untuk dipilih sebagai sampel. Sampel dalam penelitian ini adalah laporan keuangan kuartalan PT SMART Tbkperiode tahun 2011-2019. Alasan penulis menggunakan nonprobability sampling dalam Teknik pemilihan sampelnya karena data PT SMART Tbk sangatbanyak dan tidak memungkinkan untuk dihitung secara keseluruhan.

Jenis data yang digunakan dalam penelitian ini adalah data sekunder yaitu data yang diperoleh dalam bentuk sudah jadi, sudah dikumpulkan dan diolah oleh pihak lain (Sugiyono, 2010:193). Data tersebut diperoleh melalui publikasi laporan keuangan kuartalan PT SMART Tbk. periode tahun 2011- 2019.

Sumber data yang digunakan dalam penelitian ini didapatkan dari website https://www.smart-tbk.com/investor/informasi-keuangan/laporan-tahunan/. keuangan. Adapun prosedur-prosedur pengumpulan data yang dilakukan pada penelitian

ini yaitu:

1. Studi Kepustakaan (library research) merupakan metode pengumpulan data dengan studi Pustaka pada jurnal, penelitian terdahulu, dan buku- buku terkait teori yang dibahas pada penelitian ini.

2. Searching pada situs website seperti https://www.smart- tbk.com/investor/informasikeuangan/laporan-tahunan/

Metode Pengujian Data yang digunakan dalam penelitian ini : Uji Normalitas, Uji Multikolinearitas, analisis rasio, analisis korelasi analisis linier bergand, analisis koefisien determinasi serta uji hipotesis secara simultan dna parsial.

\section{HASIL DAN PEMBAHASAN}

\section{Statistik Deskriptif Data Penelitian}

Berdasarkan variabel-variabel yang dipilih oleh penulis yaitu Current Ratio (CR), Working Capital Turn Over, dan Return On Assets (ROA), data-datayang penulis gunakan merupakan data sekunder. Dimana data-data ini berasal dari situs resmi yang mengeluarkan laporan keuangan PT SMART Tbk. selamaperiode tahun 2011-2019 yang diambil dari www.smart-tbk.com. Adapun untuk mencari Current Ratio (CR), Working Capital Turn Over, dan Return On Assets (ROA), penulis menggunakan laporan keuangan PT SMART Tbk. per tahunnya lalu mengolah angka-angka yang diperlukan untuk mencari tahu hasilnya dengan menggunakan Microsoft Excel, kemudian dilakukan pengujian asumsi klasik dan regresi linear berganda dengan menggunakan software SPSS.

Kondisi Current Ratio (CR) PT SMART Tbk.

Current Ratio (CR) menunjukkan perbandingan antara aktiva lancar dengan hutang lancar. Rasio ini dapat menunjukkan kemampuan perusahaan untuk membayar kewajiban jangka pendeknya. Semakin besar nilai Current Ratio(CR), maka semakin kecil Return On Assets (ROA) PT SMART Tbk. Berikutini merupakan tabel yang menunjukkan hasil perhitungan Current Ratio (CR) pada PT SMART Tbk. tahun 2011-2019:

Tabel 5. Tabel Kondisi Current Ratio (CR)Disajikan dalam jutaan rupiah

\begin{tabular}{cccccc}
\hline No & Tahun & Triwulan & CurrentAssets & $\begin{array}{c}\text { Current } \\
\text { Liabilities }\end{array}$ & $\begin{array}{c}\text { Current } \\
\text { Ratio (CR) }\end{array}$ \\
\hline 1 & \multirow{2}{*}{2011} & I & 7.312 .816 & 4.102 .574 & 1,78 \\
2 & & II & 8.375 .851 & 4.728 .433 & 1,77 \\
3 & & III & 7.374 .375 & 4.153 .653 & 1,78 \\
4 & & IV & 7.962 .539 & 4.270 .944 & 1,86 \\
\hline 5 & & I & 7.160 .877 & 4.586 .069 & 1,56 \\
6 & \multirow{2}{*}{2012} & II & 8.307 .679 & 6.714 .859 & 1,24 \\
7 & & III & 7.911 .892 & 5.241 .612 & 1,51 \\
8 & & IV & 7.345 .444 & 3.498 .527 & 2,10 \\
\hline 9 & & I & 6.429 .553 & 2.897 .873 & 2,22 \\
10 & \multirow{2}{*}{2013} & II & 5.241 .132 & 2.661 .666 & 1,97 \\
11 & & III & 6.083 .409 & 5.009 .241 & 1,21 \\
12 & & IV & 7.661 .950 & 7.318 .180 & 1,05 \\
\hline
\end{tabular}




\begin{tabular}{cccccc}
\hline 13 & & I & 7.778 .387 & 7.021 .982 & 1,11 \\
14 & 2014 & II & 9.098 .207 & 8.947 .583 & 1,02 \\
15 & & III & 7.634 .618 & 7.224 .503 & 1,06 \\
16 & & IV & 9.712 .926 & 8.996 .931 & 1,08 \\
\hline 17 & & I & 8.840 .494 & 7.400 .002 & 1,19 \\
18 & \multirow{2}{*}{2015} & II & 11.342 .087 & 9.061 .339 & 1,25 \\
19 & III & 11.388 .598 & 11.191 .755 & 1,02 \\
20 & & IV & 10.680 .145 & 9.897 .188 & 1,08 \\
\hline 21 & & I & 9.624 .365 & 7.318 .691 & 1,32 \\
22 & \multirow{2}{*}{2016} & II & 11.151 .809 & 9.087 .970 & 1,23 \\
23 & & III & 10.879 .045 & 9.115 .586 & 1,19 \\
24 & & IV & 11.246 .586 & 8.356 .807 & 1,35 \\
\hline 25 & & I & 10.907 .826 & 8.306 .232 & 1,31 \\
26 & \multirow{2}{*}{2017} & II & 10.259 .707 & 7.051 .519 & 1,45 \\
27 & & III & 10.550 .404 & 6.775 .829 & 1,56 \\
28 & & IV & 11.163 .493 & 8.465 .263 & 1,32 \\
\hline 29 & & I & 11.652 .523 & 8.880 .186 & 1,31 \\
30 & \multirow{2}{*}{2018} & II & 14.085 .668 & 11.593 .881 & 1,21 \\
31 & & III & 12.804 .293 & 8.827 .789 & 1,45 \\
32 & & IV & 12.602 .204 & 8.452 .099 & 1,49 \\
\hline 33 & & I & 12.198 .081 & 10.969 .426 & 1,11 \\
34 & \multirow{2}{*}{2019} & II & 10.951 .081 & 9.890 .440 & 1,11 \\
35 & & III & 9.998 .909 & 9.686 .034 & 1,03 \\
36 & & IV & 11.477 .624 & 10.675 .761 & 1,08 \\
\hline
\end{tabular}

Financial

Performance in Manufacturer

Sumber : Laporan Keuangan PT SMART TBK.

Berdasarkan tabel 5. menunjukkan hasil current ratio per triwulan daritahun 2011-2019 yaitu rata-rata nilainya diatas $1,0 \mathrm{kali}$, yang artinya perusahaan tersebut dikatakan memiliki kemampuan yang baik dalam melunasi kewajibannya. Karena perbandingan aktivanya lebih besar dibanding kewajiban yang harus dibayar.

\section{Kondisi Working Capital Turnover PT SMART Tbk.}

Working Capital Turnover merupakan rasio yang digunakan untuk mengukur atau menilai keefektifan modal kerja perusahaan selama periode tertentu. Berikut ini merupakan tabel yang menunjukkan hasil perhitungan Working Capital Turnover pada PT SMART Tbk. tahun 2011-2019:

Tabel 6. Tabel Kondisi Working Capital Turnover (Disajikan dalam jutaan rupiah)

\begin{tabular}{cccccc}
\hline No & Tahun & Triwulan & $\begin{array}{c}\text { Penjualan } \\
\text { Bersih }\end{array}$ & $\begin{array}{c}\text { Modal } \\
\text { Kerja }\end{array}$ & $\begin{array}{c}\text { Working } \\
\text { Capital } \\
\text { Turnover }\end{array}$ \\
\hline 1 & & I & 7.731 .669 & 3.210 .242 & 2,41 \\
2 & \multirow{2}{*}{2011} & II & 16.347 .910 & 3.647 .418 & 4,48 \\
3 & & III & 23.762 .626 & 3.220 .722 & 7,38 \\
4 & & IV & 31.676 .219 & 3.691 .595 & 8,58 \\
\hline 5 & & I & 7.827 .009 & 2.574 .808 & 3,04 \\
6 & \multirow{2}{*}{2012} & II & 13.586 .554 & 1.592 .820 & 8,53 \\
7 & & III & 21.023 .883 & 2.670 .280 & 7,87 \\
8 & & IV & 27.526 .306 & 3.846 .917 & 7,16 \\
\hline 9 & & I & 5.589 .282 & 3.531 .680 & 1,58 \\
10 & \multirow{2}{*}{2013} & II & 11.182 .907 & 2.579 .466 & 4,34 \\
11 & & III & 16.726 .311 & 1.074 .168 & 15,57 \\
12 & & IV & 23.935 .214 & 343.770 & 69,63 \\
\hline 13 & & I & 9.072 .209 & 756.405 & 11,99 \\
14 & \multirow{2}{*}{2014} & II & 17.429 .173 & 150.624 & 115,71 \\
15 & & III & 24.978 .502 & 410.115 & 60,91 \\
16 & & IV & 32.340 .665 & 715.995 & 45,17 \\
\hline
\end{tabular}


Financial Performance in Manufacturer

\begin{tabular}{|c|c|c|c|c|c|}
\hline 17 & \multirow{4}{*}{2015} & I & 7.546 .289 & 1.440 .492 & 5,24 \\
\hline 18 & & II & 18.267 .374 & 2.280 .748 & 8,01 \\
\hline 19 & & III & 27.483 .464 & 196.843 & 139,62 \\
\hline 20 & & IV & 36.230 .113 & 782.957 & 46,27 \\
\hline 21 & \multirow{4}{*}{2016} & I & 7.946 .832 & 2.305 .674 & 3,45 \\
\hline 22 & & II & 14.181 .907 & 2.063 .839 & 6,87 \\
\hline 23 & & III & 21.033 .645 & 1.763 .459 & 11,93 \\
\hline 24 & & IV & 29.752 .126 & 2.889 .779 & 10,30 \\
\hline 25 & \multirow{4}{*}{2017} & I & 9.210 .838 & 2.601 .594 & 3,54 \\
\hline 26 & & II & 17.399 .056 & 3.208 .188 & 5,42 \\
\hline 27 & & III & 25.779 .988 & 3.774 .575 & 6,83 \\
\hline 28 & & IV & 35.318 .102 & 2.698 .230 & 13,09 \\
\hline 29 & \multirow{4}{*}{2018} & I & 8.487 .098 & 2.772 .337 & 3,06 \\
\hline 30 & & II & 17.685 .563 & 2.491 .787 & 7,10 \\
\hline 31 & & III & 27.706 .507 & 3.976 .504 & 6,97 \\
\hline 32 & & IV & 37.391 .643 & 4.150 .105 & 9,01 \\
\hline 33 & \multirow{4}{*}{2019} & I & 9.422 .832 & 1.228 .655 & 7,67 \\
\hline 34 & & II & 17.806 .394 & 1.060 .641 & 16,79 \\
\hline 35 & & III & 26.382 .930 & 312.875 & 84,32 \\
\hline 36 & & IV & 36.198 .102 & 801.863 & 45,14 \\
\hline
\end{tabular}

Sumber: Laporan Keuangan PT SMART TBK.

Berdasarkan tabel 6. menunjukkan hasil working capital turnover per triwulan dari tahun 2011-2019 yaitu nilainya fluktuatif artinya nilai setiap periodenya mengalami peningkatan dan penurunan. Jadi pada saat rasioperputaran modal kerja mengalami kenaikan hal tersebut disebabkan oleh penjualan meningkat atau modal kerja menurun. Begitupun sebaliknya, penyebab penurunan rasio perputaran modal kerja adalah karena penjualan menurun atau modal kerja meningkat.

Kondisi Return On Assets (ROA) PT SMART Tbk.

Return On Assets (ROA) merupakan rasio sebagai rentabilitas ekonomi mengukur kemampuan perusahaan menghasilkan laba dengan menggunakan total aset (kekayaan) yang dipunyai perusahaan setelah disesuaikan dengan biaya-biaya untuk mendanai asset tersebut. Rasio ini juga menunjukan produktivitas dari seluruh dana perusahaan, baik modal pinjaman maupun modal sendiri. Semakin kecil (rendah) rasio ini semakin tidak baik, demikian pula sebaliknya. Artinya rasio ini digunakan untuk mengukur efektifitas dari keseluruhan operasi perusahaan. Berikut ini merupakan tabel yang menunjukkan hasil perhitungan Return On Assets (ROA) pada PT SMART Tbk. tahun 2011-2019:

Tabel 7. Tabel Kondisi Return On Assets (ROA)Disajikan dalam jutaan rupiah

\begin{tabular}{ccccrc}
\hline \multirow{2}{*}{ No } & \multirow{2}{*}{ Tahun } & Triwulan & $\begin{array}{c}\text { Laba bersih setelah } \\
\text { pajak }\end{array}$ & TotalAktiva & $\begin{array}{c}\text { ReturnOn } \\
\text { Assets }\end{array}$ \\
\hline 1 & & I & 584.260 & 13.432 .478 & 0,04 \\
2 & \multirow{2}{*}{2011} & II & 1.159 .801 & 14.633 .126 & 0,08 \\
3 & & III & 1.493 .774 & 13.906 .258 & 0,11 \\
4 & & IV & 1.785 .737 & 14.721 .899 & 0,12 \\
\hline 5 & & I & 652.654 & 14.352 .490 & 0,05 \\
6 & \multirow{2}{*}{2012} & II & 1.112 .795 & 16.424 .230 & 0,07 \\
7 & & III & 1.588 .850 & 16.219 .049 & 0,10 \\
8 & & IV & 2.152 .309 & 16.247 .395 & 0,13 \\
\hline 9 & & I & 553.324 & 15.670 .291 & 0,04 \\
10 & \multirow{2}{*}{2013} & II & 795.631 & 15.045 .236 & 0,05 \\
11 & & III & 864.883 & 16.575 .690 & 0,05 \\
12 & & IV & 892.772 & 18.381 .114 & 0,05 \\
\hline 13 & & I & 888.166 & 18.600 .090 & 0,05 \\
14 & 2014 & II & 960.621 & 19.475 .076 & 0,05
\end{tabular}




\begin{tabular}{|c|c|c|c|c|c|}
\hline 15 & & III & 1.200 .302 & 18.154 .277 & 0,07 \\
\hline 16 & & IV & 1.474 .655 & 21.292 .993 & 0,07 \\
\hline 17 & \multirow{4}{*}{2015} & I & 78.105 & 20.841 .744 & 0,00 \\
\hline 18 & & II & 29.788 & 23.892 .813 & 0,00 \\
\hline 19 & & III & 700.832 & 24.345 .776 & $-0,03$ \\
\hline 20 & & IV & 385.509 & 23.957 .015 & $-0,02$ \\
\hline 21 & \multirow{4}{*}{2016} & I & 462.226 & 23.021 .308 & 0,02 \\
\hline 22 & & II & 2.213 .120 & 26.104 .170 & 0,08 \\
\hline 23 & & III & 2.432 .951 & 25.892 .248 & 0,09 \\
\hline 24 & & IV & 2.599 .539 & 26.141 .410 & 0,10 \\
\hline 25 & \multirow{4}{*}{2017} & I & 339.857 & 26.031 .764 & 0,01 \\
\hline 26 & & II & 488.927 & 25.411 .196 & 0,02 \\
\hline 27 & & III & 614.644 & 25.720 .056 & 0,02 \\
\hline 28 & & IV & 1.177 .371 & 27.124 .101 & 0,04 \\
\hline 29 & \multirow{4}{*}{2018} & I & 82.021 & 27.770 .033 & 0,00 \\
\hline 30 & & II & 187.019 & 30.361 .671 & $-0,01$ \\
\hline 31 & & III & 12.979 & 28.904 .404 & 0,00 \\
\hline 32 & & IV & 597.773 & 29.310 .310 & 0,02 \\
\hline 33 & \multirow{4}{*}{2019} & I & 479.524 & 28.367 .231 & 0,02 \\
\hline 34 & & II & 287.194 & 27.333 .764 & 0,01 \\
\hline 35 & & III & 531.854 & 26.616 .492 & 0,02 \\
\hline 36 & & IV & 898.698 & 27.787 .527 & 0,03 \\
\hline
\end{tabular}

Financial

Performance in Manufacturer

Sumber : Laporan Keuangan PT SMART TBK.

Berdasarkan tabel 7. menunjukkan hasil Return On Assets (ROA) per triwulan dari tahun 2011-2019 yaitu nilainya fluktuatif artinya nilai setiap periodenya mengalami peningkatan dan penurunan. Jadi Semakin kecil (rendah) rasio ini maka semakin tidak baik artinya total aktiva yang dimiliki perusahaan tidak dimanfaatkan secara baik untuk beroperasinya perusahaan, sehingga perusahaan mengalami penurunan laba atau bahkan kerugian, demikian pula sebaliknya. Semakin tinggi hasil nilai ROA maka semakin baik pula kinerja perusahaan tersebut dalam menghasilkan laba bersih atau total aktiva yang dipergunakan perusahaan untuk kebutuhan operasionalnya mampudimanfaatkan secara efisien sehingga memberikan laba bagi perusahaan.

Tabel 8. Hasil Analisis Statistik Deskriptif

NMinimum Maximum Mean Std. Deviation

\begin{tabular}{lrrrrr}
\hline Likuiditas & 36 & 102.00 & 222.00 & 137.1667 & 32.35650 \\
\hline P_M_Kerja & 36 & 158.00 & 13962.00 & 2263.8333 & 3306.52318 \\
\hline Profitabilitas & 36 & -3.00 & 13.00 & 4.3056 & 4.03428 \\
\hline Valid N (listwise) & 36 & & & & \\
\hline
\end{tabular}

Sumber: Output SPSS 25 (2021)

Pada Tabel 8. menunjukkan hasil olah data statistik deskriptif dengan menggunakan aplikasi IBM SPSS Statistics V.25 dengan jumlah total data yangdiolah adalah 36. Dari tabel 4.4 maka dapat dideskripsikan sebagai berikut:

a. Likuiditas, sebesar nilai rata-rata (mean) tingkat likuiditas adalah sebesar 137,166 dan standar deviasi atau simpangan baku sebesar 32,356 dengan jumlah data 36 sampel.

b. Perputaran modal kerja, nilai rata-rata perputaran modal kerja adalah sebesar 2263,833 dan standar deviasi atau simpangan baku sebesar 3306,523 dengan jumlah data 36 sampel.

c. Profitabilitas, nilai rata-rata profitabilitas adalah sebesar 4,305 dan standar deviasi atau simpangan baku sebesar 4,034 dengan jumlah data36 sampel.

\section{Hasil Analisis Pengujian Data}

Dalam hal ini penulis akan membahas bagaimana pengaruh Current Ratio (CR) dan Working Capital Turn Over terhadap Return On Assets (ROA) dengan melakukan pengujian menggunakan program SPSS.

Uji Asumsi Klasik 
Financial Performance in Manufacturer
Uji Normalitas

Tabel 9. Tabel Uji Normalitas

\begin{tabular}{lllr}
\hline $\mathrm{N}$ & & Unstandardized Residual \\
\hline Normal Parameters $\mathrm{a}, \mathrm{b}$ & Mean & .0000000 \\
\cline { 2 - 3 } & Std. Deviation & 3.64427617 \\
\hline Most Extreme Differences & Absolute & .142 \\
\cline { 2 - 3 } & & Positive & .142 \\
& Negative & -.128 \\
& & .142 \\
\hline Test Statistic & & $.065^{\mathrm{c}}$ \\
\hline Asymp. Sig. (2-tailed) & &
\end{tabular}

a. Test distribution is Normal.

b. Calculated from data.

c. Lilliefors Significance Correction.

Berdasarkan tabel 9. yang menunjukkan hasil pengujian normalitas data dengan menggunakan metode Kolmogorov-Smirnov, bukti empiris menunjukkan bahwa nilai Asymp. Sig. (2-tailed) memiliki nilai lebih besar dari0,05. Dengan demikian data yang digunakan penulis dikatakan normal sehingga layak digunakan untuk penelitian.

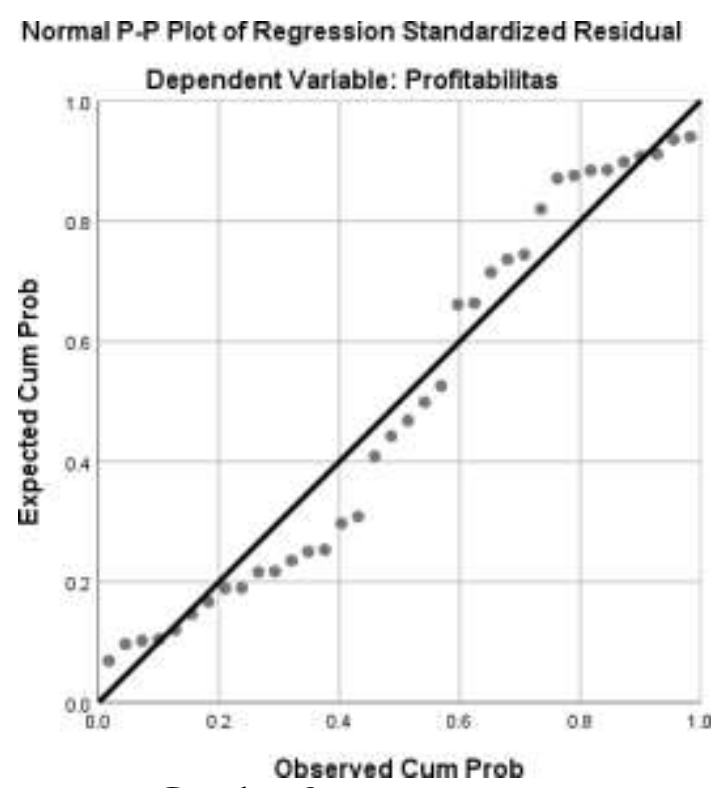

Gambar 2. Uji Normalitas dengan Pendekatan Normal Probability Plot

Berdasarkan hasil uji normalitas dengan normal probability plot (Gambar 2), titik-titik cenderung menyebar dekat dengan garis diagonal. Halini berarti data telah memenuhi asumsi normalitas.

\section{Uji Multikolinearitas}

Dalam penelitian ini penulis menggunakan nilai Variance Inflating Factor (VIF) dan tolerance dalam mendeteksi adanya gejala multikolinearitas dalam model regresi. Berikut ini merupakan interpretasi dari nilai VIF dan tolerance:

a. Jika nilai VIF tidak lebih dari 10,00 maka dapat dikatakan bahwa tidakterjadi multikolinearitas dalam model regresi.

b. Jika nilai VIF lebih dari 10,00 maka dapat dikatakan bahwa terjadi multikolinearitas dalam model regresi.

c. Jika nilai Tolerance tidak lebih dari 0,10 maka dapat dikatakan bahwaterjadi multikolinearitas dalam model regresi.

d. Jika nilai Tolerance lebih dari 0,10 maka dapat dikatakan bahwa tidak terjadi 
multikolinearitas dalam model regresi.

Tabel 10. Tabel Uji Multikolinearitas

\begin{tabular}{|c|c|c|c|c|c|c|c|c|}
\hline \multirow[b]{2}{*}{ Mode } & & \multicolumn{2}{|c|}{$\begin{array}{l}\text { Unstandardized } \\
\text { Coefficients }\end{array}$} & \multirow{2}{*}{$\begin{array}{c}\text { Standardized } \\
\text { Coefficients } \\
\text { Beta } \\
\end{array}$} & \multirow[b]{2}{*}{$\mathrm{T}$} & \multirow[b]{2}{*}{ Sig. } & \multicolumn{2}{|c|}{$\begin{array}{l}\text { Collinearity } \\
\text { Statistics }\end{array}$} \\
\hline & & $\mathrm{B}$ & Std. Error & & & & Tolerance & VIF \\
\hline 1 & (Constant) & -3.174 & 3.511 & & -.904 & .373 & & \\
\hline & Likuiditas & .054 & .023 & .435 & 2.356 & .025 & .724 & 1.380 \\
\hline & P_M_Kerja & $1.510 \mathrm{E}-5$ & .000 & .012 & .067 & .947 & .724 & 1.380 \\
\hline
\end{tabular}

a. Dependent Variable: Profitabilitas

Berdasarkan tabel 10 diketahui nilai VIF untuk variabel likuiditas (X1) dan variabel perputaran modal kerja (X2) adalah $1,380<10$. Sedangkan nilaiTolerance untuk variabel likuiditas (X1) dan variabel perputaran modal kerja (X2) adalah 0,724 $>0,10$. Karena nilai VIF kedua variabel dibawah 10 dan nilai tolerance diatas 0,10 , maka dapat dikatakan bahwa model terbebas dari gejalamultikolinearitas.

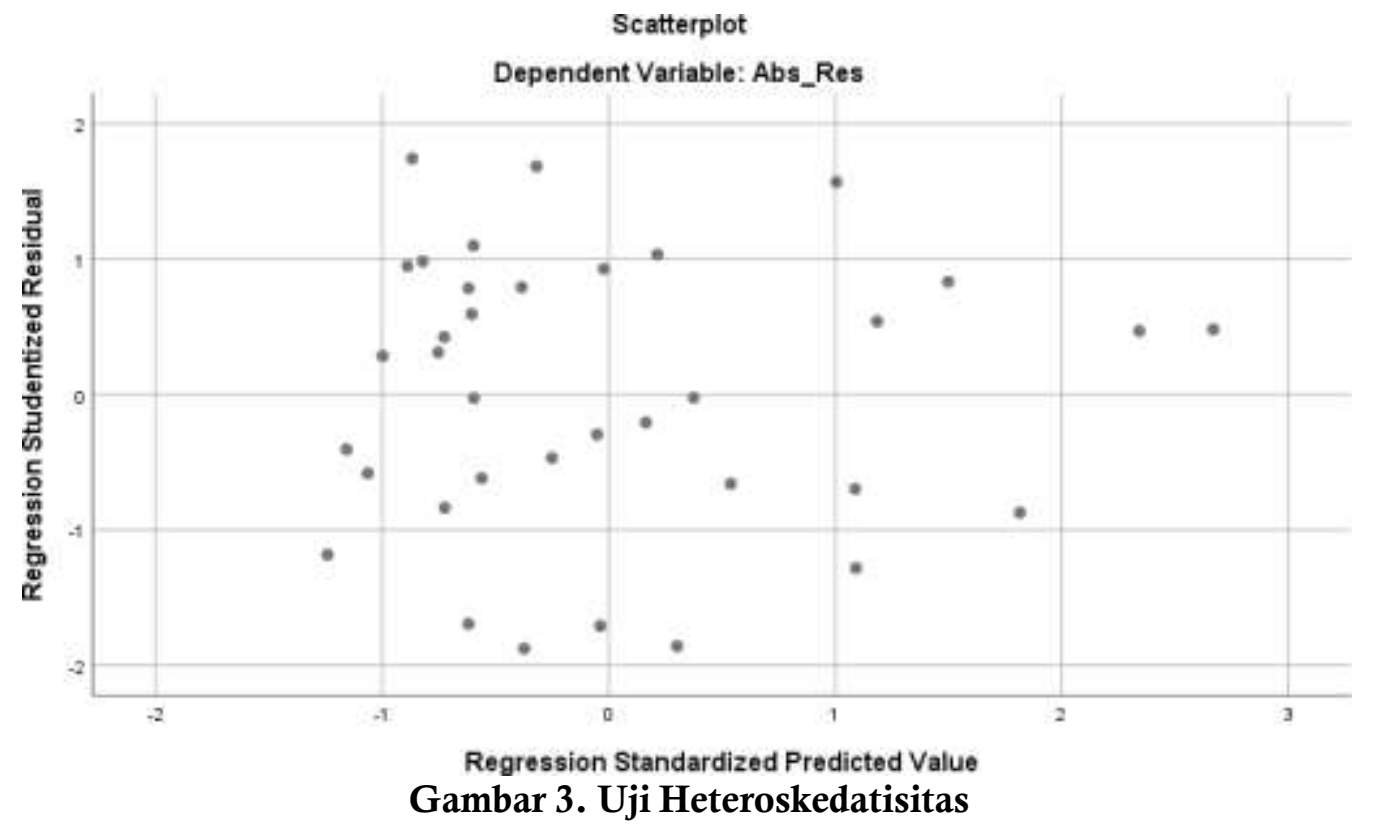

\section{Uji Heteroskedatisitas}

Gambar 3. Uji Heteroskedatisitas

Berdasarkan Gambar 3, tidak terdapat pola yang begitu jelas, serta titik-titik menyebar di atas dan di bawah angka 0 pada sumbu $Y$, maka hal ini berarti tidak terjadi heteroskedatisitas

Analisis Korelasi

Tabel 11. Tabel Analisis Korelasi

\begin{tabular}{llrrr} 
& & LikuiditasP_M_Kerja & \multicolumn{2}{c}{ Profitabilitas } \\
\hline Likuiditas & Pearson Correlation & 1 & $-.525^{* *}$ & $.429^{* *}$ \\
\cline { 2 - 5 } & Sig. (2-tailed) & 36 & .001 & .009 \\
\cline { 2 - 5 } P_M_Kerja & Pearson Correlation & $-.525^{* *}$ & 36 & 36 \\
\cline { 2 - 5 } & Sig. (2-tailed) & .001 & 1 & -.216 \\
\cline { 2 - 5 } & $\mathrm{N}$ & 36 & 36 & .205 \\
\hline Profitabilitas & Pearson Correlation & $.429^{* *}$ & -.216 & 36 \\
& Sig. (2-tailed) & .009 & .205 & 1 \\
& $\mathrm{~N}$ & 36 & 36 & 36 \\
\hline
\end{tabular}

**. Correlation is significant at the 0.01 level (2-tailed).

Financial Performance in Manufacturer 
Financial Performance in Manufacturer

\section{$\underline{384}$}

Dari output pada tabel korelasi 11. di atas, dapat melakukan penarikankesimpulan dengan merujuk pada ke-2 dasar pengambilan keputusan dalam analisis korelasi bivariate pearson di atas:

1. Berdasarkan Nilai Signifikansi Sig. (2-tailed)

Dari tabel output di atas diketahui nilai Sig. (2-tailed) antara Likuiditas (X1)dengan

Profitabilitas $(Y)$ adalah sebesar $0,009<0,05$, yang berarti terdapat korelasi yang signifikan antara variabel Likuiditas dengan variabel Profitabilitas. Selanjutnya, hubungan antara Perputaran Modal Kerja (X2) dengan Profitabilitas (Y) memiliki nilai Sig. (2-tailed) sebesar 0,205>0,05,yang berarti tidak terdapat korelasi yang signifikan antara variabel Perputaran Modal Kerja dengan variabel Profitabilitas.

2. Berdasarkan Nilai $r$ hitung (Pearson Correlations)

Diketahui nilai $r$ hitung untuk hubungan Likuiditas (X1) denganProfitabilitas (Y) adalah sebesar 0,429 > r tabel 0,329, maka dapatdisimpulkan bahwa ada hubungan atau korelasi antara variabel Likuiditas dengan variabel Profitabilitas. Selanjutnya, diketahui nilai $r$ hitung untuk hubungan Perputaran Modal Kerja (X2) dengan Proftabilitas (Y) adalah sebesar $-0,216<\mathrm{r}$ tabel 0,329, maka dapat disimpulkan bahwa tidak adahubungan atau korelasi antara variabel Perputaran Modal Kerja dengan variabel Profitabilitas.

\section{Analisis Regresi Linear Berganda}

Analisis regresi linear berganda digunakan oleh peneliti, bila penelitimeramalkan bagaimana keadaan (naik turunnya) variable dependen(kriterium), bila dua atau lebih variabel independen sebagai faktor predictordimanipulasi (dinaik turunkan nilainya). Jadi analisis regresi berganda akan dilakukan bila jumlah variabel independennya minimal 2 (Sugiyono 2017:275).Analisis regresi linear berganda digunakan untuk mengetahui ada tidaknya pengaruh dari variabel bebas terhadap variabel terikat. Pengaruhvariabel bebas (independent variable), yaitu likuiditas dan perputaran modal kerja terhadap variabel terikat (dependent variable), yaitu profitabilitas.

Penelitian ini, penulis menggunakan persamaan regresi linear bergandakarena variabel bebas dalam penelitian lebih dari satu. Adapun persamaan regresi linear berganda menurut Sugiyono (2017:275) dapat dirumuskansebagai berikut:

Keterangan :

$$
Y Y=\alpha+b b 1 X X 1+b b 2 X X 2+\varepsilon \varepsilon
$$

$\mathrm{Y}=$ Variabel Profitabilitas

$\alpha=$ Konstanta

b1 dan b2 = Koefisien regresi variabel independen

$\mathrm{X} 1=$ Variabel Likuiditas

X2 = Variabel Perputaran Modal Kerjae $=$ Standar error

Tabel 12. Tabel Analisis Regresi Linear Berganda

\begin{tabular}{|c|c|c|c|c|c|c|c|c|}
\hline \multirow[b]{2}{*}{ 1Mode } & & \multicolumn{2}{|c|}{$\begin{array}{l}\text { Unstandardized } \\
\text { Coefficients }\end{array}$} & \multirow{2}{*}{$\begin{array}{c}\text { Standardized } \\
\text { Coefficients } \\
\text { Beta } \\
\end{array}$} & \multirow[b]{2}{*}{$\mathrm{t}$} & \multirow[b]{2}{*}{ Sig. } & \multicolumn{2}{|c|}{$\begin{array}{l}\text { Collinearity } \\
\text { Statistics }\end{array}$} \\
\hline & & $\mathrm{B}$ & Std. Error & & & & Tolerance & VIF \\
\hline \multirow[t]{3}{*}{1} & (Constant) & -3.174 & 3.511 & & -.904 & .373 & & \\
\hline & Likuiditas & .054 & .023 & .435 & 2.356 & .025 & .724 & 1.380 \\
\hline & P_M_Kerja & $1.510 \mathrm{E}-5$ & .000 & .012 & .067 & .947 & .724 & 1.380 \\
\hline
\end{tabular}

a. Dependent Variable: Profitabilitas

Berdasarkan tabel 12. di atas, persamaan regresinya adalah sebagai berikut :

$\mathrm{Y}=\alpha+\mathrm{b} 1 \mathrm{X} 1+\mathrm{b} 2 \mathrm{X} 2+\mathrm{e}$

$\mathrm{Y}=-3,174+0,054 \mathrm{X} 1+1,510 \mathrm{X} 2+\mathrm{e}$

Keterangan :

$\mathrm{Y}=$ Variabel Profitabilitas

$\alpha=$ Konstanta 
b1 dan b2 = Koefisien regresi variabel independen

$\mathrm{X} 1=$ Variabel Likuiditas

X2 $=$ Variabel Perputaran Modal Kerjae $=$ Standar error

Berdasarkan model regresi di atas, dapat diartikan sebagai berikut:

1. Nilai constant adalah -3,174 mengandung arti bahwa apabila nilai variabelindependent (Likuiditas dan Perputaran Modal Kerja) adalah nol, maka nilaivariabel dependen (Profitabilitas) adalah turun sebesar -3,174.

2. Nilai koefisien regresi 0,054 artinya ketika nilai variabel independen likuiditas mengalami peningkatan satu satuan, maka akan menaikkan nilaiprofitabilitas sebesar 0,054 .

3. Nilai koefisien regresi 1,510 artinya ketika nilai variabel independentperputaran modal kerja mengalami peningkatan satu satuan, maka akan menaikkan nilai profitabilitas sebesar 1,510.

Analisis Koefisien Determinasi

Tabel 13. Tabel Koefisien Determinasi

\begin{tabular}{rr|r|r} 
Model & $\mathrm{R}$ & R Square & Adjusted R Square \\
\hline & $.429 \mathrm{a}$ & .184 & .1353 .75308
\end{tabular}

a. Predictors: (Constant), P_M_Kerja, Likuiditas

b. Dependent Variable: Profitabilitas

Berdasarkan tabel 13. diketahui nilai R Square yaitu sebesar 0,184. Halini berarti sebesar 0,184 atau 18,4\% variasi dari Profitabilitas (Y) dapat dijelaskan oleh variabelvariabel di atas yaitu Likuiditas (X1) dan Perputaran Modal Kerja (X2), meskipun $\mathrm{R}^{2}$ bernilai kecil yang berarti kemampuan variabel-variabel independen dalam menjelaskan variasi variabel dependen amat terbatas. Sedangkan sisanya sebesar 81,6\% (100\% - 18,4\% $=81,6 \%)$ dipengaruhi oleh variabel lain yang tidak dilakukan penelitian oleh penulis.

Uji Parsial (Uji t)

Tabel 14. Tabel Uji t

\begin{tabular}{|c|c|c|c|c|c|c|}
\hline \multirow[b]{2}{*}{ Mod } & \multicolumn{3}{|c|}{ UnstandardizedCoefficients } & \multirow{2}{*}{$\begin{array}{c}\text { Standardized } \\
\text { Coefficients } \\
\text { Beta }\end{array}$} & \multirow[b]{2}{*}{$\mathrm{T}$} & \multirow[b]{2}{*}{ Sig. } \\
\hline & & $\mathrm{B}$ & Std. Error & & & \\
\hline \multirow[t]{3}{*}{1} & (Constant) & -3.174 & 3.511 & & -.904 & .373 \\
\hline & Likuiditas & .054 & .023 & .435 & 2.356 & .025 \\
\hline & P_M_Kerja & $1.510 \mathrm{E}-5$ & .000 & .012 & .067 & .947 \\
\hline
\end{tabular}

a. Dependent Variable: Profitabilitas

Berikut ini adalah hasil uji hipotesis secara parsial untuk masing-masingvariabel penelitian:

1. Likuiditas

Hipotesis penelitian untuk variabel likuiditas adalah sebagai berikut:

a. $\mathrm{H} 0: \mathrm{P} 1=0$ likuiditas tidak berpengaruh signifikan terhadap profitabilitasperusahaan.

b. $\mathrm{H} 1 \neq \mathrm{P} 1=0$ likuiditas berpengaruh signifikan terhadap profitabilitas perusahaan.

Berdasarkan tabel 14. diketahui nilai Sig. untuk pengaruh X1terhadap Y adalah sebesar $0,025<0,05$ dan nilai t hitung 2,356 $>2,035$, sehingga dapat disimpulkan bahwa H0 ditolak dan $\mathrm{H} 1$ diterima yang berarti likuiditas berpengaruh terhadap profitabilitas perusahaan.

2. Perputaran Modal Kerja

Hipotesis penelitian untuk variabel perputaran modal kerja adalah sebagai berikut:

a. $\mathrm{H0}: \mathrm{P} 2=0$ perputaran modal kerja tidak berpengaruh signifikan terhadap profitabilitas perusahaan.

b. $\mathrm{H} 2 \neq \mathrm{P} 2=0$ perputaran modal kerja berpengaruh signifikan terhadap profitabilitas perusahaan.

Berdasarkan tabel 14. diketahui nilai Sig. untuk pengaruh X1terhadap Y adalah sebesar $0,947>0,05$ dan nilai t hitung $0,067<2,035$, sehingga dapat disimpulkan bahwa H0 
Financial

Performance in

Manufacturer

diterima dan $\mathrm{H} 2$ ditolak yang berartitidak terdapat pengaruh X2 terhadap Y.

Uji Simultan (Uji F)

Hipotesis penelitian untuk variabel bebas (Likuiditas dan Perputaran Modal Kerja) terhadap variabel terikat (Profitabilitas) adalah sebagai berikut:

1) $\mathrm{H} 0: \mathrm{P} 3=\mathrm{P} 3=0$ likuiditas dan perputaran modal kerja secara simultan tidak berpengaruh signifikan terhadap profitabilitas perusahaan.

2) $\mathrm{H} 3: \mathrm{P} 3 \neq \mathrm{P} 3 \neq 0$ likuiditas dan perputaran modal kerja secara simultan berpengaruh signifikan terhadap profitabilitas perusahaan.

Tabel 15. Tabel Uji F

\begin{tabular}{llrrrr|c} 
Model & & Sum of Squares & Df & Mean Square & F & Sig. \\
\hline 1 & Regression & 104.813 & 2 & 52.4063 .721 & $.035^{\mathrm{b}}$ \\
\cline { 2 - 7 } & Residual & 464.826 & 33 & 14.086 & \\
\cline { 2 - 7 } & Total & 569.639 & 35 & & \\
\hline
\end{tabular}

a. Dependent Variable: Profitabilitas

b. Predictors: (Constant), P_M_Kerja, Likuiditas

Berdasarkan tabel 15. diketahui nilai signifikansi untuk pengaruh $\mathrm{X} 1$ dan $\mathrm{X} 2$ secara simultan terhadap $\mathrm{Y}$ adalah sebesar $0,035<0,05$ dan nilai $\mathrm{F}$ hitung $\mathrm{F}$ Hitung 3,721 $>\mathrm{F}$ tabel 3,276, sehingga dapat disimpulkan bahwa H3diterima yang berarti bahwa terdapat pengaruh positif X1 dan X2 secara simultan terhadap Y.

\section{Pembahasan Hasil Penelitian \\ Pengaruh Likuiditas Terhadap Profitabilitas}

Berdasarkan uji $t$ atas pengukuran pengaruh likuiditas terhadap profitabilitas diperoleh nilai signifikansi sebesar 0,025 $<0,05$ dan nilai t hitung2,356 $>$ t table 2,035, sehingga dapat disimpulkan bahwa $\mathrm{H} 0$ ditolak dan $\mathrm{H} 1$ diterima yang berarti likuiditas berpengaruh terhadap profitabilitas perusahaan. Hasil penelitian ini sejalan dengan penelitian sebelumnya yaitu penelitian Hery Pandapotan Silitonga (2017), Rinny Meidiyustiani (2016), dimana hasil penelitian tersebut menyatakan bahwa likuiditas berpengaruh signifikan positif terhadap profitabilitas. Namun, hasil penelitian ini tidak sejalan dengan penelitian sebelumnyayaitu penelitian Selin Lumoly dkk (2018), Syarah Ajie Wijayanti (2018), dimanahasil penelitian tersebut menjelaskan bahwa likuiditas tidak berpengaruh terhadap profitabilitas perusahan.

\section{Pengaruh Perputaran Modal Kerja Terhadap Profitabilitas}

Berdasarkan uji $t$ atas pengukuran pengaruh perputaran modal kerja terhadap profitabilitas diperoleh nilai signifikansi sebesar 0,947 >0,05 dan nilait hitung 0,067 < t tabel 2,035, sehingga dapat disimpulkan bahwa $\mathrm{H} 0$ diterimadan $\mathrm{H} 2$ ditolak yang berarti tidak terdapat pengaruh X2 terhadap Y. Hasil penelitian ini sejalan dengan penelitian sebelumnya yaitu penelitian Rinny Meidiyustiani (2016), dimana hasil penelitian tersebut menjelaskan bahwa perputaran modal kerja tidak berpengaruh terhadap profitabilitas perusahan. Namun, hasil penelitian ini tidak sejalan dengan penelitian sebelumnyayaitu penelitian Danifana Maeka Fayani dkk (2013), Diarni Junita dkk (2015), Syarah Ajie Wijayanti (2018), dimana hasil penelitian tersebut menyatakan bahwa perputaran modal kerja berpengaruh signifikan terhadap profitabilitas.

\section{Pengaruh Likuiditas dan Perputaran Modal Kerja Terhadap Profitabilitas}

Berdasarkan uji $\mathrm{F}$ atas variabel independen (likuiditas dan perputaran modal kerja) diperoleh nilai signifikansi untuk pengaruh X1 dan X2 secara simultan terhadap Y adalah sebesar 0,035 <0,05 dan nilai F Hitung 3,721 > Ftabel 3,276, sehingga dapat disimpulkan bahwa $\mathrm{H} 3$ diterima yang berarti bahwaterdapat pengaruh positif X1 dan X2 secara simultan terhadap Y. Hasil analisis koefisien determinasi menunjukkan bahwa nilai koefisien determinasi (R-square) adalah 0,184. Nilai tersebut menunjukkan bahwavariabel likuiditas dan perputaran modal kerja, secara bersama-sama dapat menjelaskan hubungan terhadap variabel profitabilitas sebesar atau adanya korelasi positif antara variabel independent $(\mathrm{X})$ dengan variabel dependen $(\mathrm{Y})$ sebesar $18,4 \%$, sedangkan sisanya $81,6 \%$ merupakan pengaruh dari faktor lainyang tidak digunakan dalam penelitian ini. 


\section{PENUTUP}

Penelitian ini bertujuan untuk meneliti bagaimana pengaruh Likuiditas dan Perputaran Modal Kerja terhadap Profitabilitas. Variabel independen yang digunakan peneliti adalah likuiditas dan perputaran modal kerja, sedangkan variabel dependen yang digunakan adalah profitabilitas. Analisis yang digunakan penulis dalam penelitian ini adalah analisis regresi linear berganda dengan menggunakan program Statistical Package forSocial Sciences (SPSS) versi 25. Total sampel yang digunakan penulis sebanyak 36 data dari laporan keuangan kuartalan PT SMART Tbk. Periode tahun 2011- 2019. Berdasarkan hasil perhitungan, analisis dan pembahasan uji statistik, maka diperoleh kesimpulan sebagai berikut :

1. Likuiditas secara parsial memiliki pengaruh terhadap profitabilitas. Hasilpenelitian ini sejalan dengan penelitian sebelumnya yaitu penelitian Hery Pandapotan Silitonga (2017), Rinny Meidiyustiani (2016), dimana hasil penelitian tersebut menyatakan bahwa likuiditas berpengaruhsignifikan positif terhadap profitabilitas. Namun pada kenyataannya terkadang variabel likuiditas tidak berpengaruh terhadap profitabilitas karena perusahaan tidak memiliki kemampuan untuk memenuhi kewajiban lancar dengan aktiva lancar yang dimilikinya sehingga tidak mempengaruhi profitabilitas yang diperoleh perusahaan.

2. Perputaran modal kerja secara parsial tidak memiliki pengaruh terhadapprofitabilitas. Hasil penelitian ini sejalan dengan penelitian sebelumnya yaitu penelitian Rinny Meidiyustiani (2016), dimana hasil penelitian tersebut menjelaskan bahwa perputaran modal kerja tidak berpengaruh terhadap profitabilitas perusahan. Namun pada kenyataannya terkadang variabel perputaran modal kerja berpengaruh terhadap profitabilitas karena perusahaan dapat memaksimalkan modal kerja untuk menghasilkan penjualan yang lebih tinggi sehingga dapat meningkatkan profit perusahaan.

3. Likuiditas dan perputaran modal kerja secara simultan memiliki pengaruh terhadap profitabilitas.

\section{DAFTAR PUSTAKA}

Afriyanti, M. 2011. Analisis pengaruh Current Ratio, Total Asset Turnover, Debtto Equity Ratio, Sales dan Size Terhadap ROA, Skripsi Univeritas Diponegoro Semarang.

CNBC, Indonesia. 2020. Sinar Mas: Bisnis Sawit Mampu Bertahan Hadapi Tekanan Corona. [Internet]. [Diakses pada tanggal 27 Oktober 2020]. Tersedia pada: https://www.cnbcindonesia.com/market/20200415131228-19- $\quad$ 152103/sinarmas-bisnis-sawit-mampu-bertahan-hadapi-tekanan-corona

Danifana Maeka Fayani, Fatmasari Sukesti, dan Ayu Noviani Hanum. 2013. Pengaruh Perputaran Modal Kerja dan Perputaran Kas Terhadap Profitabilitas Perusahaan (Studi Kasus Pada Perusahaan Properti dan Perusahaan Manufaktur Yang Terdaftar Pada BEI Tahun 2010-2012). Vol.3, No. 2.

Diarni Junita, Sri Kartikowati, dan Makhdalena. 2015. Pengaruh Perputaran Modal Kerja Terhadap Tingkat Likuiditas Pada Perusahaan Properti Yang Terdaftar Di BEI Periode 2009-2013.

Elmawati Nte'esi, Marjam Mangantar, dan Victoria N. Untu. 2017. Analisis Pengaruh Perputaran Modal Kerja Terhadap Profitabilitas Perusahaan Pada PT. Indofood Sukses Makmur, Tbk. Periode 2011-2015. Jurnal EMBA. Vol.5, No.2: 289-297.

Ginanjar Indra Kusuma, Suhadak, dan Zainul Arifin. 2013. Analisis Pengaruh Profitabilitas (Profitability) Dan Tingkat Pertumbuhan (Growth) TerhadapStruktur Modal Dan Nilai Perusahaan (Studi Pada Perusahaan Real Estateand Property Yang Terdaftar Di Bursa Efek Indonesia (BEI) Periode 2007-2011.

Hartono, Jogianto. 2018. Teori Portofolio dan Analisis Investasi. BPFE Yogyakarta.

Hery Pandapotan Silitonga. 2017. Pengaruh Likuiditas dan Leverage Terhadap Profitabilitas Pada PT Japfa Comfeed Indonesia, Tbk. yang Terdaftar Di Bursa Efek Indonesia. Jurnal Financial. Vol.3, No.1.
Financial
Performance in
Manufacturer

387 
Financial

Performance in

Manufacturer

Linda Ratnasari. 2016. Pengaruh Leverage, Likuiditas, Ukuran Perusahaan Terhadap Profitabilitas Pada Perusahaan Otomotif Di BEI Periode 2009- 2014. Jurnal Ilmu dan Riset Manajemen. Vol.5, No.6.

Minanari. 2018. Pengaruh Profitabilitas, Manajemen Laba Dan Kebijakan Deviden Terhadap Nilai Perusahaan (Studi Empiris Pada PerusahaanManufaktur Yang Terdaftar Di Bursa Efek Indonesia Periode 2015-2016). Jurnal Profita. Vol.11, No.1.

PT Sinar Mas Agro Resources And Technology Tbk. 2019. Laporan Tahunan 2019 Annual Report. [Internet]. [Diakses pada tanggal 25 Oktober 2020]. Tersedia pada: https://www.smart-tbk.com/wpcontent/uploads/2020/06/AnnualReport-2019-PT-SMART-Tbk.pdf

PT Sinar Mas Agro Resources And Technology Tbk. 2018. Laporan Tahunan 2018 Annual Report. [Internet]. [Diakses pada tanggal 25 Oktober 2020]. Tersedia pada: https://www.smart-tbk.com/wp- content/uploads/2019/04/SMARTAR-2018-190430-1.pdf

PT Sinar Mas Agro Resources And Technology Tbk. 2017. Laporan Tahunan 2017 Annual Report. [Internet]. [Diakses pada tanggal 25 Oktober 2020]. Tersedia pada: https://www.smart-tbk.com/wp- content/uploads/2018/04/AnnualRepot-PT-SMART-Tbk-2017.pdf

PT Sinar Mas Agro Resources And Technology Tbk. 2016. Laporan Tahunan 2016 Annual Report. [Internet]. [Diakses pada tanggal 25 Oktober 2020]. Tersedia pada: https://www.smart-tbk.com/wp- content/uploads/2017/04/SMART$\underline{\text { AR-2016.pdf }}$

PT Sinar Mas Agro Resources And Technology Tbk. 2015. Laporan Tahunan 2015 Annual Report. [Internet]. [Diakses pada tanggal 25 Oktober 2020]. Tersedia pada: https://www.smart-tbk.com/wp- $\quad$ content/uploads/2016/08/ARSMART-2015.pdf

PT Sinar Mas Agro Resources And Technology Tbk. 2014. Laporan Tahunan 2014 Annual Report. [Internet]. [Diakses pada tanggal 25 Oktober 2020]. Tersedia pada: https://www.smart-tbk.com/wp- content/uploads/2016/08/ARSMART-2014.pdf

PT Sinar Mas Agro Resources And Technology Tbk. 2013. Laporan Tahunan 2013 Annual Report. [Internet]. [Diakses pada tanggal 25 Oktober 2020]. Tersedia pada: https://www.smart-tbk.com/wp- $\quad$ content/uploads/2016/08/ARSMART-2013.pdf

PT Sinar Mas Agro Resources And Technology Tbk. 2012. Laporan Tahunan 2012 Annual Report. [Internet]. [Diakses pada tanggal 25 Oktober 2020]. Tersedia pada: https://www.smart-tbk.com/wp- $\quad$ content/uploads/2016/08/ARSMART-2012.pdf

PT Sinar Mas Agro Resources And Technology Tbk. 2011. Laporan Tahunan 2011 Annual Report. [Internet]. [Diakses pada tanggal 25 Oktober 2020]. Tersedia pada: https://www.smart-tbk.com/wp- $\quad$ content/uploads/2016/08/ARSMART-2011.pdf

Rinny Meidiyustiani. 2016. Pengaruh Modal Kerja, Ukuran Perusahaan, Pertumbuhan Penjualan Dan Likuiditas Terhadap Profitabilitas Pada Perusahaan Manufaktur Sektor Industri Barang Konsumsi Yang TerdaftarDi Bursa Efek Indonesia (BEI) Periode Tahun 2010-2014. Jurnal Akuntansi dan Keuangan. Vol. 5, No. 2.

Selin Lumoly, Sri Murni, dan Victoria N. Untu. 2018. Pengaruh Likuiditas, Ukuran Perusahaan dan Profitabilitas Terhadap Nilai Perusahaan (Studi Pada Perusahaan Logam dan Sejenisnya yang Terdaftar di Bursa Efek Indonesia) Periode 2013-2017. Jurnal EMBA. Vol.6, No.3: 1108 - 1117.

Syarah Ajie Wijayanti. 2018. Analisis Pengaruh Likuiditas, Perputaran Modal Kerja, Dan Pertumbuhan Penjualan Terhadap Profitabilitas Perusahaan (Studi Pada Perusahaan Food and Beverages Yang Terdaftar Di BEI) Periode 2012-2016. 